\title{
CORRELATION AND PATH-COEFFICIENT ANALYSIS OF QUANTITATIVE CHARACTERS IN WINTER BREAD WHEAT VARIETIES
}

\author{
G. Desheva* \\ Institute of Plant Genetic Resources "Konstantin Malkov”, Sadovo, Bulgaria
}

\begin{abstract}
The present study was carried out to investigate the correlation and path coefficient analysis in 35 genotypes of winter bread wheat varieties, which were collected from different countries. Data were recorded for eight quantitative characters- number of productive tillers per plant, plant height, spike length, number of spikelets per spike, number of grains per spike, grain weight per spike, thousand grain weight and grain yield per plant. The highly significant and positive genotypic and phenotypic correlation was found between grain yield per plant and following components: number of productive tillers per plant $\left(r_{g}=0.817, r_{p h}=0.843\right)$, number of grains per spike $\left(r_{g}=0.448, r_{p h}=0.393\right)$, grain weight per spike $\left(r_{g}=0.765\right.$, $\left.\mathrm{r}_{\mathrm{ph}}=0.545\right)$, thousand grain weight $\left(\mathrm{r}_{\mathrm{g}}=0.594, \mathrm{r}_{\mathrm{ph}}=0.402\right)$. The number of spikelets per spike correlated positively and significantly with number of grains per spike $\left(r_{\mathrm{g}}=0.886, \mathrm{r}_{\mathrm{ph}}=0.487\right)$ and grain weight per spike $\left(\mathrm{r}_{\mathrm{g}}=0.637, \mathrm{r}_{\mathrm{ph}}=0.370\right)$. Number of grains per spike had positive and significant phenotypic and genotypic correlations with grain weight per spike $\left(r_{\mathrm{g}}=0.748, \mathrm{r}_{\mathrm{ph}}=0.826\right)$. Grain weight per spike positively correlated with thousand grains weight $\left(r_{\mathrm{g}}=0.622, \mathrm{r}_{\mathrm{ph}}=0.688\right)$. The grain weight per spike and number of productive tillers per plant had strongest direct effect on grain yield per plant. The number of grains per spike via grain weight per spike and thousand grains weight via grain weight per spike had the highest positive indirect effect on the grain yield per plant. These relations can be used as selection criteria in breeding study to improve the high yielding cultivars for that region.
\end{abstract}

Key words: genotypic correlations, path coefficient analysis, phenotypic correlations, winter bread wheat, yield components

\section{INTRODUCTION}

The grain yield in the wheat is a complex character that can be determined by several components which reflect positive or negative effects upon this trait. It is important to examine the contribution of each of the various components in order to attract the attention to which one has the greatest influence on grain yield. Therefore, information on the relation of yield components with grain yield is of great importance to a breeder in selecting a desirable genotype (1). Correlations between traits are depending of genetic and environmental factors. Environmental conditions can cause variability, not only of some trait but interrelationships between its (2). Simple correlation analysis

*Correspondence to: Gergana Desheva, Institute of Plant Genetic Resources "Konstantin Malkov", Druzhba str.2, 4122 Sadovo, Bulgaria, gergana_desheva@abv.bg indicates the degree of association between traits, but it can't provide reasons of association.

Therefore, simple correlation coefficients are not always effective in determining the real relationships among traits (3). Path analyses provide a measure of relative importance of each independent variable to prediction of changes in the dependent one. A path coefficient is a standardized partial regression coefficient and as such measures the direct effect of one trait upon other and permits the separation of correlation coefficient into direct and indirect effects (4). Path coefficients show direct influence independent variable upon dependent variable. Indirect influence on independent variable through other independent variable on dependent variable is describe results between coefficient simple correlation two independent of variables and their separate direct influence (5). Path analysis was used in numerous researches with the aim of determining the effects of important 
yield components (6-17). The knowledge of genetic and phenotypic interrelationships between yield and quantitative/qualitative components of yield is giving additional information that is make possible successful work of wheat breeding.

The objective of this study was to establish the interrelationship and direct and indirect effects of some yield components among themselves and with grain yield in winter bread wheat.

\section{MATERIALS AND METHODS}

The present study was conducted in the experimental field of Institute of Plant Genetic Resources "Konstantin Malkov"-Sadovo, Bulgaria during 2011-2014 growing seasons. Thirty five wheat varieties from different countries (Bulgaria, Rumania, Serbia, Hungary, China and Ukraine) were examined. The experiment was conducted in the randomized block design in three replications and $10 \mathrm{~m}^{2}$ plot size. Normal agronomic and cultural practices were applied to the experiment throughout the growing seasons. The agronomic characters were taken after harvesting the plants. From each variety, 20 plants were collected for biometrical measurements. Data were recorded for number of productive tillers per plant, plant height, spike length, number of spikelets per spike, number of grains per spike, grain weight per spike, thousand grain weight and grain yield per plant.

Genotypic correlations were calculated by using of genotypic variances and covariance, phenotypic correlations by using phenotypic variances and covariance. The genotypic and phenotypic correlations thus calculated were tested for significance (5). The path coefficient analysis was performed according Dewey and $\mathrm{Lu}$ (4), using genotypic correlations to assess direct and indirect influences of different yield components (productive tillers per plant, plant height, spike length, number of spikelets per spike, number of grains per spike, grain weight per spike and thousand grain weight) on grain yield per plant.

\section{RESULTS AND DISCUSSION \\ Genotypic and phenotypic correlations}

Genotypic and phenotypic correlation coefficients provide a quantitative evaluation of effects of environments on particular character (18). The association of grain yield per plant with other characters was estimated by genotypic and phenotypic correlation coefficients (Table 1). Highly significant and positive genotypic and phenotypic correlation existed between grain yield per plant and four different traits are: number of productive tillers per plant $\left(\mathrm{r}_{\mathrm{g}}=0.817\right.$, $\left.r_{p h}=0.843\right)$, number of grains per spike $\left(r_{g}=0.448\right.$, $\left.\mathrm{r}_{\mathrm{ph}}=0.393\right)$, grain weight per spike $\left(\mathrm{r}_{\mathrm{g}}=0.765\right.$, $\left.\mathrm{r}_{\mathrm{ph}}=0.545\right)$, thousand grain weight $\left(\mathrm{r}_{\mathrm{g}}=0.594\right.$, $\mathrm{r}_{\mathrm{ph}}=0.402$ ). These results are in agreement with results obtained by Khaliq et al., Uddin et al., Narwal et al., Ashfaq et al. and Nayeem et al. (18-22). The phenotypic correlation between grain yield per plant and number of spikelets per spike was positive and significant at the 0.05 level $\left(r_{p h}=0.292\right)$. Number of productive tillers per plant also had positive and significant phenotypic correlation with number of grain per spike $\left(r_{\mathrm{g}}=0.328\right)$, grain weight per spike $\left(r_{g}=0.328\right)$ and thousand grain weight $\left(r_{g}=0.218\right)$. The genotypic and phenotypic correlations between number of productive tillers per plant and spike length was negative and significant $\left(r_{g}=-0.340, r_{p h}=-0.190\right)$. Plant height and spike length had significant and positive genotypic and phenotypic correlation $\left(r_{\mathrm{g}}=0.427, \mathrm{r}_{\mathrm{ph}}=0.368\right)$, what was confirmed by Zecevic et al. (23). Plant height and thousand grain weight was positively and significantly correlated $\left(\mathrm{r}_{\mathrm{g}}=0.316\right.$, $r_{p h}=0.179$ ), what was in agreement with the study carried out by Khaliq et al., Zecevic et al. and Bhatt $(18,23,24)$. The genotypic and phenotypic correlations between plant height, number of spikelets per spike and number of grains per spike were negative and significant at the 0.05 and 0.01 levels. Spike length was in positive and significant phenotypic correlation with number of spikelets per spike $\left(\mathrm{r}_{\mathrm{ph}}=0.353\right)$ and with grain weight per spike $\left(\mathrm{r}_{\mathrm{ph}}=0.164\right)$. This is in agreement with the result obtained by Khaliq et al. (18). Genotypic and phenotypic correlations between spike length, number of grains per spike and thousand grain weight were also significant and positive. The number of spikelets per spike correlated positively and significantly with number of grains per spike $\left(\mathrm{r}_{\mathrm{g}}=0.886, \mathrm{r}_{\mathrm{ph}}=0.487\right)$ and grain weight per spike $\left(r_{\mathrm{g}}=0.637, \mathrm{r}_{\mathrm{ph}}=0.370\right)$. Number of grains per spike was in positive and significant phenotypic and genotypic correlations with grain weight per spike $\left(r_{\mathrm{g}}=0.748, \mathrm{r}_{\mathrm{ph}}=0.826\right)$ and also in positive phenotypic correlation with thousand grains weight $\left(r_{p h}=0.179\right)$. Grain weight per spike correlated positively and high significantly with thousand grain weight $\left(r_{g}=0.622, r_{p h}=0.688\right)$. This is in agreement with results obtained by Zecevic et al. and Dolotovskiy et. al. (23, 25). Positive correlation was determined between thousand grain weight and grain yield per plant. This result confirmed the findings of Khan et al., Khaliq et al., Shachid et al. and Okuyama et al. $(2,18,26,27)$. 
DESHEVA G.

Table 1. Genotypic $\left(r_{g}\right)$ and phenotypic $\left(r_{p h}\right)$ correlation coefficients of investigation yield components in winter bread wheat

\begin{tabular}{|c|c|c|c|c|c|c|c|c|c|}
\hline Variable & & $\begin{array}{l}\text { Number of } \\
\text { productive } \\
\text { tillers per } \\
\text { plant }\end{array}$ & $\begin{array}{l}\text { Plant } \\
\text { height }\end{array}$ & $\begin{array}{l}\text { Spike } \\
\text { length }\end{array}$ & $\begin{array}{l}\text { Number } \\
\text { of } \\
\text { spikelets } \\
\text { per } \\
\text { spike }\end{array}$ & $\begin{array}{l}\text { Number } \\
\text { of } \\
\text { grains } \\
\text { per } \\
\text { spike }\end{array}$ & $\begin{array}{l}\text { Grain } \\
\text { weight } \\
\text { per } \\
\text { spike }\end{array}$ & $\begin{array}{l}\text { Thousand } \\
\text { grain } \\
\text { weight }\end{array}$ & $\begin{array}{l}\text { Grain } \\
\text { yield } \\
\text { per } \\
\text { plant }\end{array}$ \\
\hline \multirow{2}{*}{$\begin{array}{l}\text { Number of } \\
\text { productive tillers per } \\
\text { plant }\end{array}$} & $r_{g}$ & 1.000 & & & & & & & \\
\hline & $r_{\mathrm{ph}}$ & 1.000 & & & & & & & \\
\hline \multirow{2}{*}{ Plant height } & $\mathrm{r}_{\mathrm{g}}$ & 0.078 & 1.000 & & & & & & \\
\hline & $\mathrm{r}_{\mathrm{ph}}$ & 0.080 & 1.000 & & & & & & \\
\hline \multirow{2}{*}{ Spike length } & $r_{g}$ & $-0.340^{*}$ & $0.427 *$ & 1.000 & & & & & \\
\hline & $\mathrm{r}_{\mathrm{ph}}$ & $-0.190 * *$ & $0.368 * *$ & 1.000 & & & & & \\
\hline \multirow{2}{*}{$\begin{array}{l}\text { Number of spikelets } \\
\text { per spike }\end{array}$} & $\mathrm{r}_{\mathrm{g}}$ & 0.093 & $-0.365^{*}$ & 0.220 & 1.000 & & & & \\
\hline & $\mathrm{r}_{\mathrm{ph}}$ & $0.145^{*}$ & $-0.205 * *$ & $0.353 * *$ & 1.000 & & & & \\
\hline \multirow{2}{*}{$\begin{array}{l}\text { Number of grains } \\
\text { per spike }\end{array}$} & $r_{g}$ & 0.220 & $-0.404 *$ & $0.503 * *$ & $0.886^{* *}$ & 1.000 & & & \\
\hline & $r_{p h}$ & $0.257 * *$ & $-0.202 * *$ & $0.355^{* *}$ & $0.485^{* *}$ & 1.000 & & & \\
\hline \multirow{2}{*}{$\begin{array}{l}\text { Grain weight per } \\
\text { spike }\end{array}$} & $r_{g}$ & $0.362 *$ & -0.145 & 0.154 & $0.637 * *$ & $0.748 * *$ & 1.000 & & \\
\hline & $r_{\mathrm{ph}}$ & $0.328 * *$ & -0.059 & $0.164 *$ & $0.370 * *$ & $0.826^{* *}$ & 1.000 & & \\
\hline \multirow{2}{*}{$\begin{array}{l}\text { Thousand grain } \\
\text { weight }\end{array}$} & $r_{g}$ & 0.269 & 0.316 & $0.364 *$ & -0.055 & -0.052 & $0.622 * *$ & 1.000 & \\
\hline & $\mathrm{r}_{\mathrm{ph}}$ & $0.218 * *$ & $0.179 *$ & $0.156^{*}$ & 0.026 & $0.179 *$ & $0.688 * *$ & 1.000 & \\
\hline \multirow{2}{*}{ Grain yield per plant } & $r_{g}$ & $0.817 * *$ & -0.060 & -0.317 & 0.214 & $0.448^{* *}$ & $0.765 * *$ & $0.594 * *$ & 1.000 \\
\hline & $r_{p h}$ & $0.843 * *$ & 0.002 & -0.109 & $0.292 * *$ & $0.393 * *$ & $0.545^{* *}$ & $0.402 * *$ & 1.000 \\
\hline
\end{tabular}

*Correlation is significant at the 0.05 level

**Correlation is significant at the 0.01 level

\section{Path coefficient analysis}

Path coefficient analysis helps to determine the contribution of various components of yield to over all grain yields in the genotypes under study. It provides an effective way of finding out direct and indirect sources of correlation $(2,18$, 27).

The direct effect of grain weight per spike on grain yield were found to be important in the numerous studies $(9 ; 28-37)$. Our results showed that grain weight per spike had the greatest positive effect (1.692) on yield grain per plant, followed by number of productive tillers per plant (0.610) (Table 2). The effect of the others traits were negative direction towards reducing the yield. Especially number of grains per spike had a prominent effect on yield grain per plant in negative direction with (-0.939), what is in agreement with result reported by Yagdi (13).

The direct effect of thousand grains weight on yield grain per plant was also negative and high $(-0.670)$, while plant height and number of spikelets per spike had minimum negative direct effect on the yield (-0.096 and -0.021), respectively. Plant height had positive indirect effect via number of grains per spike (0.304), while negative effects through grain weight per spike and thousand grain weight on grain yield per plant. Spike length affected the grain yield negatively via number of grains per spike (0.429). The indirect effect of number of spikelets per spike through number of grains per spike was negative $(-0.687)$, while it was positive through grain weight per spike (0.860). Number of grains per spike had the highest positive indirect effect (1.316) via grain weight per spike. Thousand grain weight also had an appreciable indirect effect (1.104) via grain weight per spike (Table 2).

The path coefficient analysis gave a somewhat different picture from what the simple correlation analysis did. The genotypic correlation analysis indicated that number of grains per spike and thousand grain weight as important positive influences on grain yield per plant, but path coefficient analysis suggested that they had direct negative influence on grain yield per plant. The direct negative effects of number of grains per spike and thousand grain weight on the grain yield were masked from the positive indirect effect of these characters through grain weight per spike. 
Table 2. Direct (Bold and Underline) and indirect effect of 7 characters (independent variables) on grain yield per plant (dependent variable) in 35 wheat genotypes. The last column shows genotypic correlations of independent variables with grain yield plant

\begin{tabular}{|c|c|c|c|c|c|c|c|c|c|}
\hline \multirow[b]{2}{*}{ Variable } & \multicolumn{7}{|c|}{ Direct and indirect effect } & \multirow[b]{2}{*}{$\begin{array}{l}\text { Total } \\
\text { indirect } \\
\text { effect }\end{array}$} & \multirow[b]{2}{*}{$r_{g}$} \\
\hline & $\begin{array}{l}\text { Number } \\
\text { of } \\
\text { productive } \\
\text { tillers per } \\
\text { plant }\end{array}$ & $\begin{array}{l}\text { Plant } \\
\text { height }\end{array}$ & $\begin{array}{l}\text { Spike } \\
\text { length }\end{array}$ & $\begin{array}{l}\text { Number } \\
\text { of } \\
\text { spikelets } \\
\text { per spike }\end{array}$ & $\begin{array}{l}\text { Number } \\
\text { of } \\
\text { grains } \\
\text { per } \\
\text { spike }\end{array}$ & $\begin{array}{l}\text { Grain } \\
\text { weight } \\
\text { per } \\
\text { spike }\end{array}$ & $\begin{array}{l}\text { Thousand } \\
\text { grain } \\
\text { weight }\end{array}$ & & \\
\hline $\begin{array}{l}\text { Number of } \\
\text { productive tillers / } \\
\text { plant }\end{array}$ & $\underline{0.610}$ & -0.009 & 0.042 & -0.003 & -0.222 & 0.573 & -0.174 & 0.207 & $0.817 * *$ \\
\hline Plant height & 0.043 & $\underline{-0.096}$ & 0.052 & 0.006 & 0.304 & -0.186 & -0.184 & 0.035 & -0.061 \\
\hline Spike length & -0.191 & 0.032 & $\underline{-0.151}$ & -0.011 & -0.429 & 0.243 & 0.190 & -0.166 & -0.317 \\
\hline $\begin{array}{l}\text { Number of } \\
\text { spikelets per spike }\end{array}$ & 0.063 & 0.026 & -0.039 & $\underline{-0.021}$ & -0.687 & 0.860 & 0.012 & 0.235 & 0.214 \\
\hline $\begin{array}{l}\text { Number of grains } \\
\text { per spike }\end{array}$ & 0.146 & 0.031 & -0.058 & -0.013 & $\underline{-0.939}$ & 1.316 & -0.035 & 1.387 & $0.448 * *$ \\
\hline $\begin{array}{l}\text { Grain weight per } \\
\text { spike }\end{array}$ & 0.231 & 0.021 & -0.014 & -0.008 & -0.725 & $\underline{1.692}$ & -0.432 & -0.927 & $0.765^{* *}$ \\
\hline $\begin{array}{l}\text { Thousand grain } \\
\text { weight }\end{array}$ & 0.166 & -0.016 & 0.050 & 0.002 & -0.042 & 1.104 & $\underline{-0.670}$ & 1.264 & $0.594 * *$ \\
\hline
\end{tabular}

\section{CONCLUSION}

The results obtained from 35 bread wheat genotypes showed that grain yield per plant was significantly and positively correlated with number of productive tillers per plant, number of grains per spike, grain weight per spike and thousand grain weight both at genotypic and phenotypic levels. Path coefficient analysis indicated that the direct effects of plant height, spike length and number of spikelets per spike on grain yield were weakly negative. The direct effects of grain weight per spike and number of productive tillers per plant were strongly positive, while number of grains per spike and thousand grain weight had strongly negative effect. Therefore, the characters of grain weight per spike, number of productive tillers per plant, number of grains per spike and thousand grain weight can be used as selection criteria to increase grain yield in bread wheat in the region.

\section{REFERENCES}

1. Ozer , H., Oral, E., Dodru, U. Relationships between yield and yield components on currently improved spring rapeseed cultivars. Tur. Journal of Agriculture and Foresty, 23: 603-607, 1999.
2. Khan, A. J., Azam, F., Ali, A., Tariq, M. and Amin, M., Inter-relationship and phat coefficient analysis for biometric traits in drought tolerant wheat (Triticum aestivum L.). Asian Journal of Plant Sciences, 4 (5): 540-543, 2005.

3. Hardwick, R. C. and Andrews, D. J., Genetics and environmental variation in crop yield of estimating the interdependence of components of yield. Euphytica, 20: 177-188, 1980.

4. Dewey, R. D. and Lu, K. H., A correlation and path coefficient analysis of components of crested wheat grass seed production. Agronomy Journal, 52: 515-8, 1959.

5. Lidansky, T., Statistical methods in the biology and in the agriculture. Zemizdat, Sofia, 1988.

6. Maria, J. O. Z , Rosielle, A. A., Waines, J. G., Foster, K. W., A heritability and correlation study of grain yield, yield components and harvest index of common bean in sole crop and intercrop. Field Crops Research, 9: 109-118, 1984.

7. Stafford, R. E. and Seiler, G. J., Path coefficient analysis of yield components in guar. Field Crops Research, 14: 171-179, 1986. 
8. Costa, J. M. and Krostand, W. E., Association of grain protein concentration and selected traits in hard red winter wheat populations in the Pacific Northwest. Crop Science, 34:1234-1239, 1994.

9. Akanda, S. I. and Mundt, C. C, Path coefficient analysis of the effects of stripe rust and fed conditions. Pakistan Journal Agriculture Research, 17: 1-6, 1996.

10.Dogney, M. L., Gour, V. K. and Mehta, A. K., Path coefficient analysis of yield attributing characters in backcross. Crop Research, 16 (3): 352-357, 1998.

11. Mehetre, S. S., Shinde, R. B., Borle, U. M. and Suraa, P., Correlation and path analysis studies of partioning in root growth and yield characters in soybean (Glycine max (L.) Merill). Crop Research (Hisar), 13 (2): 415-422, 1997.

12.Ball, A. R., McNew, R. W., Vories, E. D., Keisling, T. C. and Purcell, L. C., Path analysis of population density effects on short-season soybean yield. Agronomy Journal, 93: 187-195, 2001.

13. Yagdi, K., Path coefficient analysis of some yield components in durum wheat (Triticum durum Desf.). Pakistan journal of botany, 41(2): 745-751, 2009.

14.Naazar, A., Javidfar, F., Elmira, J. Y. and Mirza, M. Y., Relationship among yield components and selection criteria for yield improvement in winter rapeseed (Brassica napus L.). Pakistan Journal of Botany, 35(2): 167-174, 2003.

15.Ahmed, H. M., Khan, B. M., Khan, S., Kissana, N. and Laghari, S., Path coefficient analysis in bread wheat. Asian Journal of Plant Science, 2(6): 491-494, 2003.

16.Georgiev, S., Stamatov, S. and Deshev, M., Examination of the selection criteria in sesame (Sesamum indicum L.) using phenotypic correlations and Path analysis. Agricultural Sciences, 4(10): 71-76, 2012.

17.Getachew, W. M., Sentayehu, A. and Taye, K., Genotypic correlation and path coefficient analysis of organoleptic quality attributes of some Ethiopian specialty coffee (Coffea arabica L.) accessions. Sky Journal of Agricultural Research, 3(3): 046 $-052,2014$.

18. Khaliq, I., Parveen, N. and Chowdhry, M. A., Correlation and path coefficient analyses in bread wheat. International journal of agriculture and biology, 6 (4): 633-635, 2004.

19.Uddin, M. J., Mitra, B., Chowdhry, M. A. Z. Genetic parameters, correlation pathcoefficient and selection indices in wheat. Bangladesh. Journal of Science and Industry Researce, 32: 528-38, 1997.
20.Narwal, N. K., Verma, P. K. and Narwal, M. S., Genetic variability, correlation and path coefficient analysis in bread wheat in two climatic zones of Haryana. Agric.Sci. Diget. Karnal., 19: 73-6, 1999.

21.Ashfaq, M., Khan, A. S. and Ali, Z., Association of morphological traits with grain yield in wheat. Journal of Agriculture and Biology, 5: 262-4, 2003.

22.Nayeem, K. A. and Baig, K. S, Correlation studies in durum wheat. J.Res. Angrau., 31:116-21, 2003.

23.Zecevic, V., Knezevic, D. and Micanovic, D., Genetic correlations and pathcoefficient analysis of yield and quality components in wheat (Triticum aestivum L.). Genetika, 36(1):13-21, 2004.

24.Bhatt, G. M., Significance of path coefficient analysis in determining the nature of character association. Euphytica, 22: 338-343, 1973.

25.Dolotovskiy, I. M. and Nikonov, V. I., Genetic correlations of some yield components in spring wheat. Russia. Plant breeding and Seed Production, 4:19-21, 1989.

26.Shahid, F., Mohammad, F., Tahir, M., Path coefficient analysis in wheat. Sarhad Journal of Agriculture, 18: 383-388, 2002.

27. Mohsin, T., Khan, N. and Naqvi, F. N., Heritability, phenotypic correlation and path coefficient studies for some agronomic characters in synthetic elite lines of wheat. Journal of Food, Agriculture and Environment, 7(3, 4): 278 - 282, 2009.

28. Okuyama, L. A., Luiz, C. F. and Neto, J. F., Correlation and path analysis of yield and its components and plant traits in wheat. Ciencia Rural, 34: 1701-1708, 2004.

29.De Pauw, Shebeski, I. H., An evaluation of early generation yield testing procedure in T. aestivum. Canadian Journal of Plant Science, 53: 465-470, 1973.

30.Boyadjieva, D., Possibility for increase of effectiveness in the breeding selection of winter bread wheat. Zemizdat, Sofia, 1988.

31.Aruna, C. and Raghavaiah, P., Correlations and analysis of yield and quality in aestivum wheat (Triticum aestivum L.). Journal of Research ANGRAU, 25(4): 2125, 1997.

32.Shou Fu, X., FengJun, W., Runsheng, J., Correlation analysis of several quantitative characters of barley. Barley Genetics Newsletter: 27, 1997. (in: http://wheat. Pw.usda. gov/gpages/bgn/27/xfltxt.html).

33. Moghaddam, M., Ehdaie, B. and Waines, J. G., Genetic variation for and interrelationships among agronomic traits in landraces of bread wheat from 
southwestern Iran. Journal of Genetics and Breeding, 52(1): 73-81, 1998.

34.Dokuyucu, T. and Akaya, A., Path coefficient analysis of correlation of grain yield and yield components of wheat (Triticum aestivum L.) genotypes. Rachis, 18(2): 17-20, 1999.

35.Dencic, S., Kastori, R., Kobiljski, B. and Duggan, B., Evaluation of grain and its components in wheat cultivars and landraces under near optimal and drought conditions. Euphytica, 113: 43-52, 2000.

36.Ismail, A. A., Identification of selection traits for yield improvement of bread wheat using path analysis. Assuit Journal of Agricultural Sciences, 32(2): 63-84, 2001.

37.Yagdi, K., The correlation and path coefficient analysis for yield and some yield components of common wheat ( Triticum aestivum L.) in bursa ecological conditions. Journal of Uludag University Agricultural Faculty, 15: 11-18, 2001.

38.Aycicek, M. and Yildirim, T., Path coefficient analysis of yield and yield components in bread wheat (Triticum aestivum L.) genotypes. Pakistan journal of botany, 38(2): 417-424, 2006. 